\title{
INNERVATION OF THE MEDIAN NERVE MOTOR BRANCHES IN THE FOREARM AND ITS CLINICAL SIGNIFICANCE
}

\author{
INERVAÇÃO DOS RAMOS DO NERVO MEDIANO NO \\ ANTEBRAÇO E SUA SIGNIFICANCIA CLIINICA
}

\author{
Edie Benedito Caetano ${ }^{1}$ (i), JoÃo Paulo Nunes Toledo ${ }^{1}$ (i), SÉrgio aparecido do amaral Júnior ${ }^{1}$ (i),

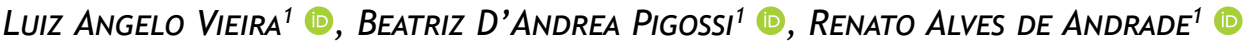

1. Pontifícia Universidade Católica de São Paulo, School of Medical and Health Sciences, Department of Surgery, Sorocaba, SP, Brazil.

\section{ABSTRACT}

Objective: To analyse the anatomical variations of the median nerve motor branches in the elbow region. Methods: Twenty upper limbs of 10 adult male cadavers were prepared by intra-arterial injection of a solution of $10 \%$ glycerol and formaldehyde. All cadavers belonged to the institution anatomy laboratory. Results: We found a great variability within the distribution of median nerve branches leading to forearm muscles. Only three limbs (14\%) presented the normal standard of innervation described in anatomy treatises. The pronator teres muscle (PTM), flexor carpi radialis (FCR), palmaris longus (PL), and the flexor digitorum superficialis (FDS) received exclusive innervation from the median nerve in all forearms. The anterior interosseous nerve (AIN) also originated from the median nerve in all dissected limbs. Conclusion: A thorough understanding of the anatomy of the median nerve branches is important for performing surgeries such as: approach to the proximal third of the forearm, alleviation of pronator teres and anterior interosseous nerve compression syndromes, and distal nerve transfers. It also enables a better understanding the recovery of muscle function after a nerve injury. Level of Evidence IV, Case series.

Keywords: Peripheral Nerve Injuries. Nerve Transfer. Mewdian Nerve.

\section{RESUMO}

Objetivo: Analisar as variações anatômicas dos ramos motores do nervo mediano na região do cotovelo. Avaliamos origem, curso, comprimento, terminações nervosas dos ramos e suas relações com estruturas vizinhas. Métodos: Selecionamos 20 membros de 10 cadáveres adultos dissecados, preparados por injeção intra-arterial com solução de glicerina e formol a 10\%. Todos do sexo masculino, pertencentes ao laboratório de anatomia da instituição. Resultados: O primeiro ramo do nervo mediano no antebraço foi o músculo pronador redondo. A distribuição dos ramos do nervo mediano para os músculos do antebraço mostrou grande variabilidade. Apenas 3 membros (14\%) apresentaram padrão normal de inervação descrito nos tratados de anatomia. Os músculos pronador redondo, flexor radial do carpo, palmar longo e flexor superficial dos dedos receberam inervação exclusiva do nervo mediano em todos os antebraços. O nervo interósseo anterior originou-se do nervo mediano nos membros dissecados. Conclusão: Conhecer a anatomia dos ramos motores do nervo mediano é importante para realizar procedimentos cirúrgicos na região como a abordagem do terço proximal do antebraço, por exemplo a liberação das síndromes compressivas do pronador redondo e do nervo interósseo anterior; as transferências nervosas distais; também entender a ordem de recuperação da função muscular após uma lesão nervosa. Nível de Evidência IV, Série de casos.

Descritores: Traumatismos dos Nervos Periféricos. Transferência de Nervo. Nervo Mediano.

Citation: Caetano EB, Toledo JPN, Amaral SA Jr, Vieira LA, Pigossi BD, Andrade RA. Innervation of the median nerve motor branches in the forearm and its clinical significance. Acta Ortop Bras. [online]. 2020;28(5):251-255. Available from URL: http://www.scielo.br/aob.

\section{INTRODUCTION}

The median nerve (MN) is formed by the union of the lateral and medial cords of the brachial plexus and contains the nerve fibres from the spinal roots, from C5 to T1. In the proximal third of the arm, it is located in the middle part of the biceps, alongside the brachial artery and vein. In the proximal arm, it is situated next to the brachial artery. In the middle third of the arm, it crosses the brachial artery in front from lateral to medial side, lying on its middle. In the distal humerus, it runs the antecubital fossa through the brachial muscle (BM) and the intermuscular septum, underneath the bicipital aponeurosis (lacertus fibrosus). It then passes between the two heads of the pronator teres muscle (PTM) and penetrates the arch formed by the proximal muscle insertions of the flexor digitorum superficialis (FDS)., ${ }^{1,2}$

Nerves associated with forearm muscles, named primary, separate from the main branch of the median nerve in the distal third of the

All authors declare no potential conflict of interest related to this article.

The study was conducted at Pontifícia Universidade Católica de São Paulo, Department of Surgery of the School of Medical and Health Sciences.

Correspondence: Edie Benedito Caetano. Rua Joubert Wey, 290, Sorocaba, SP, Brazil, 18030230. ediecaetano@uol.com.br 
arm and from the proximal forearm. From these, secondary branches emerge. Primary and secondary branches penetrate muscle mass by the radial nerve motor branch. ${ }^{3}$ The normal innervation pattern of forearm muscles by the MN is described as follows: two branches (upper and lower) to the PTM, a common trunk to the flexor carpi radialis (FCR) and palmaris longus $(\mathrm{PL})$, a branch to the flexor digitorum profundus, and a branch to the anterior interosseous nerve (AIN), which innervates the flexor digitorum profundus (FDP), flexor pollicis longus (FPL), and pronator quadratus (PQ). ${ }^{4,5}$

Later anatomical studies reported that MN distribution may differ from this classic pattern. ${ }^{3,6-11}$ Gunther et al. ${ }^{9}$ classified the branches into six groups, considering location and ramification. Canovas et al. ${ }^{6}$ found considerable variability in the branches to muscles innervated by the $\mathrm{MN}$, without a clear innervation pattern. Chantelot et al. ${ }^{10}$ observed that the classic distribution was applicable to only $26 \%$ of the their studied limbs. Safwat et al. ${ }^{7}$ studied the radial nerve motor branch for all forearm muscles, defined as nerve branch entry points into muscle.

Knowing MN motor branches is important for performing surgical procedures in the region of the forearm, such as: (1) approach to the proximal third of the forearm; (2) alleviation of PTM compressive syndromes; (3) distal nerve transfers of redundant nerve branches; and (4) a better understanding of the recovery of muscle function after a nerve injury.

This study aimed to analyse the anatomic variations of median nerve motor branches in the elbow region considering origin, course, length, ramifications, motor points, and relation to adjacent structures using 20 cadaver limbs. Considering that our results differ from various anatomic studies, the variability within this region should be emphasized.

\section{MATERIALS AND METHODS}

Twenty upper body limbs of ten male cadavers were prepared by intra-arterial injection of a solution of $10 \%$ glycerol and formaldehyde solution. Each forearm was dissected with the elbow extended and forearm supinated. Limbs showed no evidence of previous deformities, surgical procedures, or traumatic injuries in the studied area. The skin and fascia from the third distal of the arm and forearm were removed. The median nerve (MN) was identified and dissected from proximal to distal. The bicipital aponeurosis was sectioned and the humeral head of the pronator teres muscle (PTM) was distally removed and retracted. The tendons of the flexor carpi radialis (FCR) and palmaris longus $(\mathrm{PL})$ were sectioned in their third distal to make their motor branches more visible. MN branches to PTM, FCR, PL, flexor digitorum superficialis (FDS), and anterior interosseous nerve (AIN) for flexor digitorum profundus (FDP), flexor pollicis longus (FPL), and pronator quadratus (PQ) were dissected and anatomical variations recorded. Vascular structures were not preserved to facilitate nerve dissection. A magnifying glass of 2,5 times magnification was employed at certain phases of the dissection.

Each muscle innervation order and the number of branches and motor points - defined as nerve branch entry points into the musclewere recorded. Branch diameter and length to muscles PT, PL, FDS, AIN, and FCR were measured using a digital pachymeter and a millimetre ruler. All available specimens adhered to the ethical principles of the institution and the project was evaluated by the Ethics in Research Committee and registered in the Plataforma Brasil, under CAAE No. 14643419.5.0000.5373.

\section{RESULTS}

We described muscles following the order by which they emerged from the median nerve, from proximal to distal, in most limbs. Average forearm length was $26,2 \pm 2,7 \mathrm{~cm}$. Charts 1, 2, and 3 (Table 1, 2, and 3) summarizes average diameter, number of primary branches, and motor points of each muscle.
In all forearms, the pronator teres (PTM) was the first forearm muscle to be innervated and received exclusive innervation of the median nerve (MN) (Figure 1). PTM branches emerged from the MN in an interval 6,8 cm above and 2,8 cm below the humeral intercondylar line. We found more than one branch from the PTM in 14 limbs (70\%) (Figure 2).

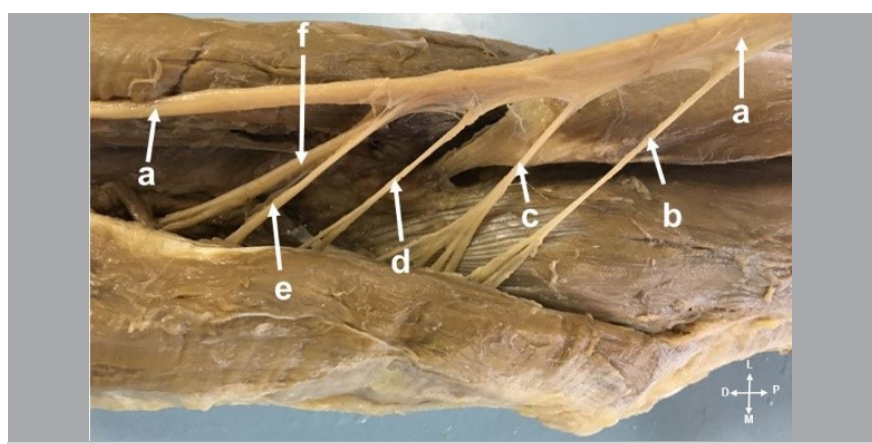

Figure 1. (a): Median nerve; (b): PT branch; (c): FCR branch; (d): PL branch; (e): FDS branch; (f): AIN.

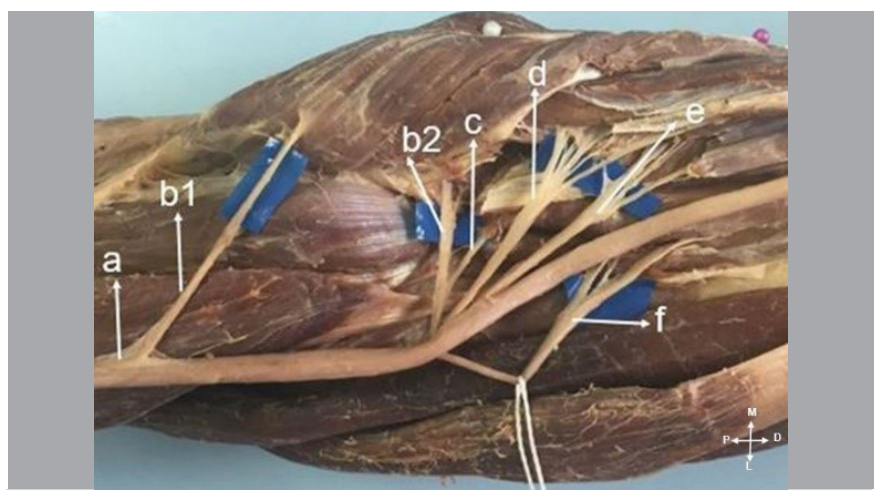

Figure 2. (a): Median nerve; (b1 and b2): PT branch; (c): PL branch; (d): FCR branch; (e): FDS branch; (f): AIN.

We found no palmaris longus (PL) muscle in 3 limbs (14\%). However, when present, it was the second muscle innervated by the MN (Figure 1). In 5 limbs (19,7\%), the PL received an exclusive innervation from a sole branch of the median nerve, shared with no other muscles. In 3 limbs, its origin was shared with the flexor carpi radialis (FCR) (Figure 3 ).

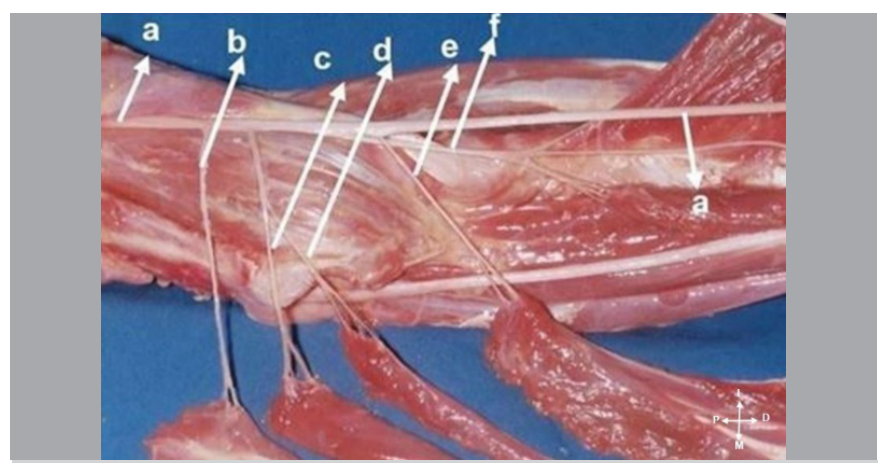

Figure 3. (a): Median nerve; (b): PT branch; (c): FCR branch; (d): PL branch; (e): FDS branch; (f): AIN.

All limbs presented the FCR with a sole branch. In most cases, it was the third forearm muscle innervated by the $\mathrm{MN}$, receiving an exclusive innervation in all limbs (Figures 1 and 3). 
In 14 limbs (70\%), the anterior interosseous nerve (AIN) originated in the nervous fascicles of the MN posterior region, whereas in 6 limbs (30\%) it originated in the posterolateral fascicles of the MN (Figure 4). Regarding the number of ramifications destined to the FPL and flexor digitorum profundus (FDP) muscles that penetrated in different points of their muscle masses, 6 limbs (305) presented two branches for the FMF and one for the FPL; 6 limbs (30\%) had two branches for both FDP and FPL; 4 limbs (20\%) three branches for the FDP and one for the FPL; and 4 limbs (20\%) three branches for the FDP and two for the FDS. In all cases, the longest ramification always led to the FPL (Figure 5).

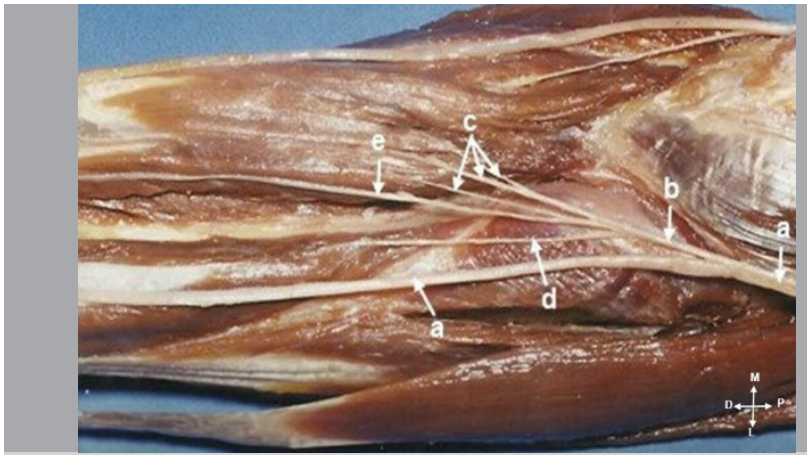

Figure 4. (a): Median nerve; (b): AIN; (c): branches to FDP; (d): branches to FPL; (e) branch to PQ.

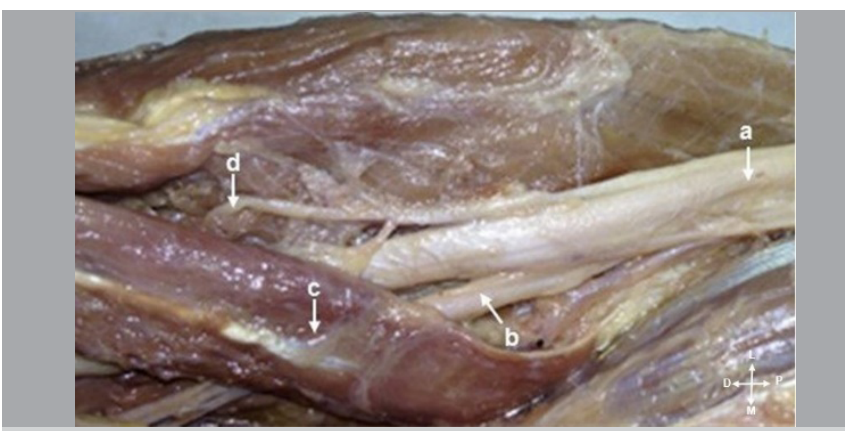

Figure 5. (a): Median nerve; (b): AIN; (c): superficial head of PT muscle; (d): PT branch.

In all limbs, the flexor digitorum superficialis (FDS) muscle received innervation by the $\mathrm{MN}$, and was the last branch to emerge. In one $\operatorname{limb}(0,5 \%)$, the branch originated further up, slightly under the origin of the branch for the PTM. In two limbs (10\%), despite receiving innervation of the $\mathrm{MN}$, the FDS also received a branch from the AIN. As in 13 limbs (65\%) the FDS received a sole branch of the $\mathrm{MN}$, in 7 limbs (35\%) it received two branches (Figure 6).

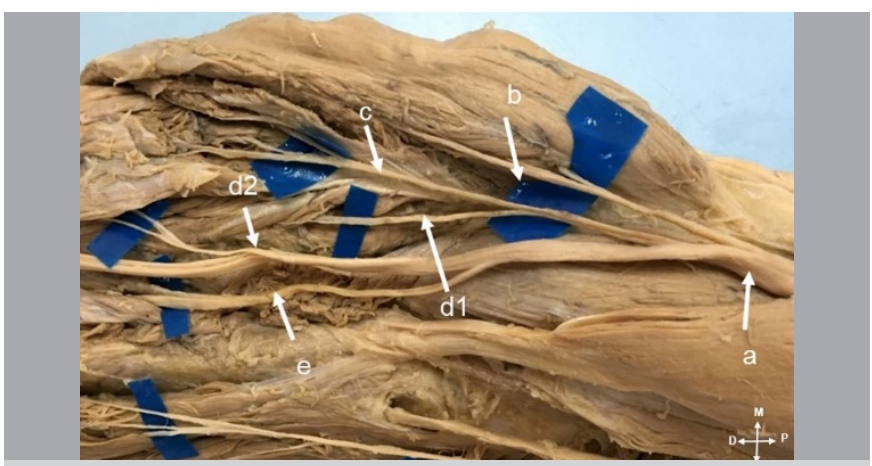

Figure 6. (a): Median nerve; (b): PT branch; (c): FCR branch; (d): PL branch; (d1 and d2): FDS branches; (e): AIN.
Table 1. Number, average diameter, and average length of median nerve branches in 20 limbs.

\begin{tabular}{c|c|c|c|c}
\hline Muscle & $\begin{array}{c}\text { Number } \\
\text { of primary } \\
\text { branches }\end{array}$ & $\begin{array}{c}\text { Average nerve } \\
\text { diameter (mm) }\end{array}$ & $\begin{array}{c}\text { Average nerve } \\
\text { lenght (mm) }\end{array}$ & Limbs \\
\hline Pronator teres & 1 to 3 & $1.5 \pm 0.6$ & $4.0(3.0 \pm 5.2)$ & 20 \\
\hline Palmaris longus & $\begin{array}{c}1-\text { absent } \\
\text { in limbs }\end{array}$ & $1.4 \pm 0.7$ & $3.7(2.9 \pm 4.7)$ & 20 \\
\hline $\begin{array}{c}\text { Flexor carpi radialis } \\
\text { Flexor digitorum } \\
\text { superficialis }\end{array}$ & 1 & $1.5 \pm 0.6$ & $3.8(3.0 \pm 4.5)$ & 20 \\
\hline $\begin{array}{c}\text { Anterior } \\
\text { interosseous nerve }\end{array}$ & 1 & $1.7 \pm 0.6$ & $4.2(2.5 \pm 5.0)$ & 20 \\
\hline $\begin{array}{c}\text { Flexor digitorum } \\
\text { produnfus }\end{array}$ & 1 to 3 & $1.0 \pm 0.8$ & $1.0 \pm 0.5$ & 20 \\
\hline $\begin{array}{c}\text { Flexor pollicis } \\
\text { longus }\end{array}$ & 1 to 2 & $1.0 \pm 0.6$ & $1.0 \pm 0.5$ & 20 \\
\hline $\begin{array}{c}\text { Pronador } \\
\text { quadratus }\end{array}$ & 1 & $1.2 \pm 0.5$ & $-\cdots+1.2$ & 20 \\
\hline $\begin{array}{c}\text { fle----- } \\
(8.5 \pm 11.0)\end{array}$ & 20 \\
\hline
\end{tabular}

Table 2. Summary of muscle motor points innervated by the median nerve in the middle proximal and distal third of the forearm.

\begin{tabular}{c|c|c|c|c|c|c}
\hline Muscle & $\begin{array}{c}1 \text { motor } \\
\text { point }\end{array}$ & $\begin{array}{c}\mathbf{2} \text { motor } \\
\text { points }\end{array}$ & $\begin{array}{c}3 \text { motor } \\
\text { points }\end{array}$ & $\begin{array}{c}4 \text { motor } \\
\text { points }\end{array}$ & $\begin{array}{c}5 \text { motor } \\
\text { points }\end{array}$ & $\begin{array}{c}\text { Average } \\
\text { motor } \\
\text { points }\end{array}$ \\
\hline Pronator teres & 2 & 8 & 6 & 4 & ------- & $2.4 \pm 0.8$ \\
\hline $\begin{array}{c}\text { Flexor carpi } \\
\text { radialis }\end{array}$ & 4 & 13 & 3 & ------ & -------- & $2.0 \pm 0.4$ \\
\hline Palmaris longus & 10 & 8 & 2 & ----- & & $1.8 \pm 0.8$ \\
\hline $\begin{array}{c}\text { Flexor digitorum } \\
\text { superficialis }\end{array}$ & 2 & 10 & 6 & 2 & ------ & $2.0 \pm 0.6$ \\
\hline $\begin{array}{c}\text { Anterior } \\
\text { interosseous } \\
\text { nerve }\end{array}$ & ----- & 3 & 10 & 7 & & $3.0 \pm 0.7$ \\
\hline
\end{tabular}

Table 3. Summary of the median motor points distribution along the muscle. Number of muscle motor points innervated by the radial nerve in the middle proximal and distal thirds of the forearm.

\begin{tabular}{|c|c|c|c|c|c|}
\hline $\begin{array}{l}\text { Muscle } \\
\text { name }\end{array}$ & $\begin{array}{c}\text { Average } \\
\text { motor points }\end{array}$ & $\begin{array}{c}\text { Muscle } \\
\text { proximal } \\
\text { third }\end{array}$ & $\begin{array}{c}\text { Proximal } \\
\text { and third } \\
(\%)\end{array}$ & $\begin{array}{c}\begin{array}{c}\text { Distal } \\
\text { third } \\
(\%)\end{array} \\
\end{array}$ & $\begin{array}{c}\text { Entire } \\
\text { muscle belly } \\
\text { extension (\%) }\end{array}$ \\
\hline $\begin{array}{c}\text { Pronator } \\
\text { teres }\end{array}$ & $2.4 \pm 0.8$ & $20(100 \%)$ & -------- & -..--..- & -..--..-..- \\
\hline $\begin{array}{c}\text { Flexor carpi } \\
\text { radialis }\end{array}$ & $2.0 \pm 0.4$ & $20(100 \%)$ & & -. & -.---.--.- \\
\hline $\begin{array}{c}\text { Palmaris } \\
\text { longus }\end{array}$ & $2.0 \pm 0.6$ & $20(100 \%)$ & & -..--..- & -.------- \\
\hline $\begin{array}{c}\text { Anterior } \\
\text { interosseous } \\
\text { nerve }\end{array}$ & $3.0 \pm 0.7$ & $6(30 \%)$ & $14(70 \%)$ & -.---.- & $100 \%$ \\
\hline
\end{tabular}

\section{DISCUSSION}

Great anatomical treatises - such as those by Rouvière et al., ${ }^{4}$ and Paturet - often describe the distribution of the median nerve (MN) in the forearm as follows: two branches (upper and lower) for the pronator teres muscle (PTM), a common trunk to the flexor carpi radialis (FCR) and the palmaris longus (PL), and a branch to the flexor digitorum superficialis (FDS). However, recent studies revealed considerable anatomical variations within this pattern. ${ }^{6-12}$ Dogan et al. ${ }^{12}$ analysed MN motor branches in 200 extremities of 100 foetuses and observed different ramification patterns than 
those classically reported by previous studies, suggesting that the latter variation should be revisited and reconsidered.

Sunderland et al. ${ }^{8}$ studied 20 cadavers upper body limbs and provided the perhaps most detailed biometric description, although not mentioning the PL muscle. They identified, in 18 out of 20 limbs (90\%), the presence of more than one branch for the FDS and, in 14 out of 20 limbs (70\%), several branches for the PTM. Canovas et al. ${ }^{6}$ dissected 10 limbs and found a significant variability among branches for muscles innervated by the MN, especially for the PTM, FCR, PL, and FDS with no clear innervation pattern, and a lower variation for the anterior interosseous nerve (AIN). El Zawawy et al. ${ }^{3}$ analysed 20 cadaver limbs and found a great variety in MN distribution to the PT, FCR, PL, and FDS, stating that anatomical treatises classic description would hardly be found. Chantelot et al. ${ }^{10}$ found variable ramification patterns in most of the 50 dissected limbs: in only $40 \%$ of the cases they found the classic distribution from a common trunk of the MN to the FCR and PL.

Gunther et al. ${ }^{9}$ classified MN branches into six groups, according to their location and ramifications, whereby: group I included branches for the PTM; group II for the FCR, PL, and FDS; group III the AIN; group IV the distal branch for the FDS; and groups V and $\mathrm{VI}$ comprised small additional branches of the MN for the FDS in the middle and distal third of the forearm. They found a greater variability within group II, which often shared the branches of groups I and II, and a greater invariability within groups IV and VI. They also found that, in some cases, branches could be affected by proximal MN neurolysis along distances ranging from $7-9 \mathrm{~cm}$. Tung et al. ${ }^{11}$ results corroborate those reported by Gunther et al. ${ }^{9}$ Raouf et al. ${ }^{13}$ reported that such innervation variations by the $\mathrm{MN}$ may be associated with muscle anomalies, as the presence of duplicate or accessory muscles, or PL absence.

In our study, we found great variability within the distribution of the branches of the MN to forearm muscles. Only 3 limbs (15\%) presented the classic innervation pattern described in anatomical treatises. In all dissected limbs, the PTM, FCR, PL, and FDS received exclusive innervation from the MN.

While the concept of nerve transfer to handle brachial plexus injuries is not new, distal nerve transfers is a novel technique. According to Tung et al.,11 acknowledging these anatomical details is not an absolute clinical necessity when preparing for a nerve transfer to restore finger extension, but enables an identification of such nerve branches. They also provided a detailed description of what is required to perform a nerve transfer to restore forearm paralysed muscles: donor nerve must be dispensable (for instance, FCR function may be executed by the PL, if present, and by the ulnar carpi flexor) or redundant (for instance, 14 limbs presented more than one branch for the PTM and 11 limbs for the FDS). ${ }^{11}$

For Fuss et al., ${ }^{14}$ correlating clinical signs and symptoms to surgical anatomy may cause some confusion due to the controversies related to innervation sequence recorded in the literature. The classic description is prone to critics because it suggests that: (1) each muscle receives no more than one branch; and (2) ramifications follow a logical sequence (for instance, Chantelot et al. ${ }^{10}$ identified the classic sequence described in the main anatomical treatises in $40 \%$ of their studied cases, and we identified it only in only $14 \%$ ). Most of our cases presented motor branches in the sequence: PTM, PL, FCR, FDS, and AIN. However one limb showed FDS origin slightly under the origin of the branch for the PTM and, in two limbs, despite the innervation by the $M N$, it received a branch from the AIN. Whereas in 13 limbs the FDS received only one branch of the $\mathrm{MN}$, in 7 limbs it received two branches.

We analysed the number of motor points - nerve branches entry points in the muscle - of the PTM, FCR, PL, FDS, and AIN muscles, and observed that most of them were located in the proximal third of the muscles (Table 3). Segal et al. ${ }^{15}$ addressed the association between the number of motor points and neuromuscular compartments, stating that each motor point corresponds to one neuromuscular compartment, which works independently from other compartments. This explains why muscles with more complex functions, such as finger flexors and extensors, have more motor points than other forearm muscles. Knowing the location of nerve branches and motor points facilitates the insertion of electrodes at the motor points of forearm muscles to functional electrical stimulation in upper motor neuron lesions. ${ }^{3}$

Our results may also be useful for procedures of selective denervation to rebalance spastic muscles. ${ }^{3,7}$ Liu et al. ${ }^{16}$ report that forearm injuries (even in cases where the main nerve trunks are intact), as crushing injuries in the in segmental, damage the muscles either by direct damage or by damage to their motor points.

We suggest surgical approaches of MN branches in the elbow region to be performed with the patient in supine, horizontal decubitus position, with the upper limb resting on a hand surgery table and the back of their elbow facing the surgeon. We recommend an incision of approximately $7 \mathrm{~cm}$ above the elbow flexion crease, alongside the middle of the biceps brachii. The surgeon should lean in front of the elbow towards its crease, somehow parallel to it. The incision is completed distal, running the back of the forearm alongside the middle edge of the brachialis (BR) muscle. The skin and subcutaneous cell tissue must be cut pulling apart the skin tears in the middle and lateral. The following structures will be identified on top of the brachial fascia crossing the elbow: cephalic vein, basilic vein, elbow medial, and forearm medial.

Provided other more important structures are not at risk, these structures must be preserved as much as possible. Then, the aponeurotic expansion of the biceps brachii muscle (lacertus fibrosus), which goes in the middle towards the ulna and crosses the brachial artery and vein and the MN, must be performed. At the cubital fossa level, the brachial artery is located next to the $\mathrm{MN}$ and the brachial vein. In this region, the $\mathrm{MN}$ branches to flexor-pronator muscles, originates the AIN, and continues through the two PTM heads. Then, it follows under the two heads, originating the upper flexor.

\section{CONCLUSION}

We found a great variability in the innervation of forearm muscles. Only 3 limbs (14\%) presented the classic innervation patterns described by the main anatomical treatises. Knowing the anatomy of $\mathrm{MN}$ motor branches is important when performing surgical procedures in the region of the forearm, as in operations in the proximal third of the forearm, such as the alleviation of PTM and AIN compressive syndromes, distal nerve transfers. It also enables a greater understanding of the recovery of muscle function after a nerve injury.

AUTHORS' CONTRIBUTIONS: Each author contributed individually and significantly to the development of this article. EBC: writing of the manuscript, statistical analysis of the data, intellectual concept of the manuscript and development of the research project, critical analysis of the intellectual concept and final approval of the manuscript; JPNT: data collection, data analysis, writing and revision of the manuscript; SAAJ: data collection, data analysis, writing and revision of the manuscript; LAV: data collection, analysis and revision of the manuscript, intellectual concept writing of the manuscript, statistical analysis of the data, and intellectual concept of the manuscript and development of the research project; BDP: data collection, data analysis, writing and revision of the manuscript; RAA: data collection, data analysis, writing and revision of the manuscript. 


\section{REFERENCES}

1. Spinner M. Injuries to the major branches of the peripheral nerves of the forearm Philadelphia: Saunders; 1978.

2. Johnson RK, Spinner M, Shrewsbury MM. Median nerve entrapment syndrome in the proximal forearm. J Hand Surg Am. 1979;4(1):48-51.

3. El Zawawy EM, El Sekily NM, Fouad WA, Emam MH, Hassan MM. Median nerve motor entry points in the forearm - clinical application. Eur $\mathrm{J}$ Anat. 2016;20(1):1-17.

4. Rouvière $H$, Delmas $A$. Anatomie humaine: descriptive, topographique et fonctionnelle. Paris: Masson; 1984.

5. Testut L, Latarjet A. Traité d'anatomie humaine. Paris: G Doin \& Cie; 1930

6. Canovas F, Mouilleron P, Bonnel F. Biometry of the muscular branches of the median nerve to the forearm. Clin Anat. 1998;11(4):239-45.

7. Safwat MD, Abdel-Meguid EM. Distribution of terminal nerve entry points to the flexor and extensor groups of forearm muscles: an anatomical study. Folia Morphol. 2007;66(2):83-93.

8. Sunderland S, Ray LJ. Metrical and non-metrical features of the muscular branches of the median nerve. J Comp Neurol. 1946;85(2):191-203.

9. Gunther SF, DiPasquale D, Martin R. The internal anatomy of the median nerve in the region of the elbow. J Hand Surg Am. 1992;17(4):648-56.
10. Chantelot C, Feugas C, Guillem P, Chapnikoff D, Rémy F, Fontaine C. Innervation of the medial epicondylar muscles: an anatomic study in 50 cases. Surg Radio Anat. 1999;21:165-8.

11. Tung TH, Mackinnon SE. Flexor digitorum superficialis nerve transfer to restore pronation: two case reports and anatomic study. J Hand Surg Am. 2001;26(6):1065-72.

12. Dogan NU, Uysal II, Karabulut AK, Fazliogullari Z. The motor branches of median and ulnar nerves that innervate superficial flexor muscles: a study in human fetuses. Surg Radiol Anat. 2010;32(3):225-33.

13. Raouf HA, Kader GA, Jaradat A, Dharap A, Fadel R, Salem AH. Frequency of palmaris longus absence and its association with other anatomical variations in the Egyptian population. Clin Anat. 2013;26(5):572-7.

14. Fuss FK, Wurzl GH. Median nerve entrapment pronator teres syndrome. Surg Radiol Anat. 1990;12(4):267-71.

15. Segal RL. Neuromuscular compartments in the human biceps brachii muscle. Neurosci Lett. 1992;140(1):98-102.

16. Liu J, Pho RW, Pereira BP, Lau HK, Kumar VP. Distribution of primary motor nerve branches and terminal nerve entry points to the forearm muscles. Anat Rec. 1997;248(3):456-63. 